\title{
Full mouth rehabilitation utilizing implant-assisted removable partial denture with a canted occlusal plane: a case report
}

\author{
A-Reum Han', Tae-Min Kwon', Kyoung-A Kim², Jae-Min Seo* \\ ${ }^{1}$ Department of Prosthodontics, School of Dentistry and Institute of Oral Bio-Science, Chonbuk National University, Jeonju, \\ Republic of Korea \\ ${ }^{2}$ Department of Dentistry, School of Medicine, Eulji University, Daejeon, Republic of Korea
}

Implant-assisted removable partial denture (Implant-assisted RPD, IARPD), posterior edentulous extension areas of which obtains additional support and retention from implants, is attracting increasing interest. This case report presents a successful treatment on a partially edentulous patient with a severely canted occlusal plane resulted from a long-term use of posterior extended RPD. The full mouth was rehabilitated through a fixed prosthesis on maxilla and IARPD with zirconia occlusal surface on mandible, which allowed to achieve an esthetic occlusal plane with long-term stability and, ultimately, functionally satisfying outcome. (J Dent Rehabil Appl Sci 2016;32(3):214-23)

Key words: implant; implant-assisted removable partial denture; partial edentulism; occlusal plane

\section{서론}

부분 무치악 환자에서 임플란트를 이용한 고정성 보 철이 상실치를 효과적으로 대체할 수 있으나 치조골 흡 수가 심한 경우 경제적 부담과 해부학적 한계와 시술의 어려움, 그리고 광범위한 수술에 대한 환자의 거부감 등 의 이유로 여전히 통상적인 가철성 보철을 이용한 수복 이 병행되고 있다. ${ }^{1,2}$ 그러나 후방 연장 국소의치의 경우 지렛대 작용에 의하여 의치상이 회전하며, 무치악부의 지 속적인 골흡수와 이로 인한 의치상의 동요를 야기하고, 하부 연조직을 자극하며, 저작 기능의 회복이 불완전하 여 환자의 만족도는 높지 않다. ${ }^{3}$ 이를 장기간 사용할 경우 후방 잔존 치조제의 흡수와 지대치의 손상 및 교합평면 의 부조화와 수직고경의 변화 등이 발생할 수 있다.

후방 연장 국소의치에서 후방 의치상의 회전은 치아와

*Correspondence to: Jae-Min Seo

Professor, Department of Prosthodontics, School of Dentistry and Institute of Oral Bio-Science, Chonbuk National University, 567, Baekje-daero, Deokjin-gu, Jeonju, 54896, Republic of Korea

Tel: +82-63-250-2696, Fax: +82-63-250-2218, E-mail: jmseo@jbnu.ac.kr

Received: July 11, 2016/Last Revision: July 26, 2016/Accepted: August 3, 2016
점막의 서로 다른 조직의 물리적 특성에서 기인하므로 치 아-조직 지지 구조인 Kennedy class I 또는 II 국소의치에 서 발생하고, 후방 무치악 부위에 임플란트를 식립 하면 class III 형태의 치아-임플란트 지지 구조로 변환할 수 있 다. ${ }^{4-6}$ 이와 같은 형태의 임플란트 보조 국소의치는 의치 의 안정과 유지의 향상으로 환자에게 편안함을 주고, 저 작 능력과 심미성 개선 및 경제적 측면에서도 장점이 있 다. ${ }^{2,3}$

본 증례는 장기간 후방연장 국소의치의 사용으로 인하 여 심하게 기울어진 교합평면을 가진 부분 무치악 환자 에서 상악의 고정성 보철 수복과 하악의 지르코니아 교 합면을 가지는 임플란트 보조 국소의치를 이용하여 심미 적이며 장기적으로 안정적인 교합평면을 가지도록 전악 수복하였으며, 기능적으로 만족스러운 결과를 얻었기에 이를 보고하고자 한다.

Copyright@ 2016 The Korean Academy of Stomatognathic Function and Occlusion. (c) It is identical to Creative Commons Non-Commercial License. 


\section{증례보고}

환자는 66세 여성으로 잔존 지대치의 통증 및 오래된 의치의 불편감을 주소로 본과에 내원하셨으며, 약 20년 전에 제작한 상, 하악 Kennedy class I 국소의치를 사용 하고 있었다. 초진 시 구내 사진 및 파노라마 방사선 사진 상에서 교합평면의 기울어짐(canting)으로 전치부의 비 심미성과 장기간 후방연장 국소의치의 사용으로 인한 무 치악부 치조제의 흡수가 관찰되며, 의치상의 침하 및 인 공치의 마모에 의한 \#26, 44, 45 대합치의 정출이 일어나 교합평면의 부조화를 보였다(Fig. 1, 2).

진단 과정에서 관찰된 내용을 근거로 기울어진 교합 평면의 개선을 동반한 기능성과 심미성을 회복하기 위해 전악 수복하기로 결정하였다. 환자는 심미성을 위한 전 치부 치아의 고정성 수복을 요구하였으며, 동시에 기능 적이면서도 경제적인 치료를 원하였다. 따라서 상악은
$\# 11,12,14,21,22,24$ 자연치아와 \#15, 16, 17, 25, 27 임플란트를 이용한 고정성 보철 수복을, 상대적으로 무 치악 범위가 넓은 하악은 \#33, 44, 45 자연치를 이용하 여 전방부 고정성 보철 제작 후, 치조골 흡수량이 큰 후 방 무치악 부위에 \#37, 47 임플란트 식립하여 임플란트 보조 국소의치로 수복하기로 하였다. 하악 임플란트 보

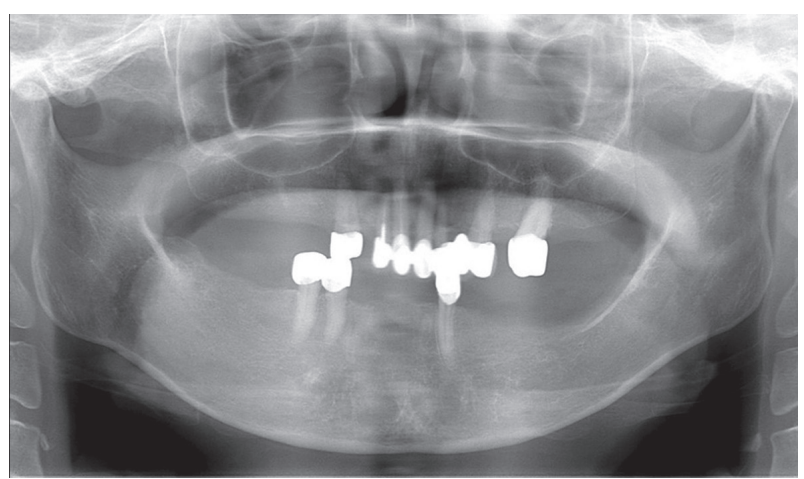

Fig. 1. Pre-treatment panoramic radiograph.

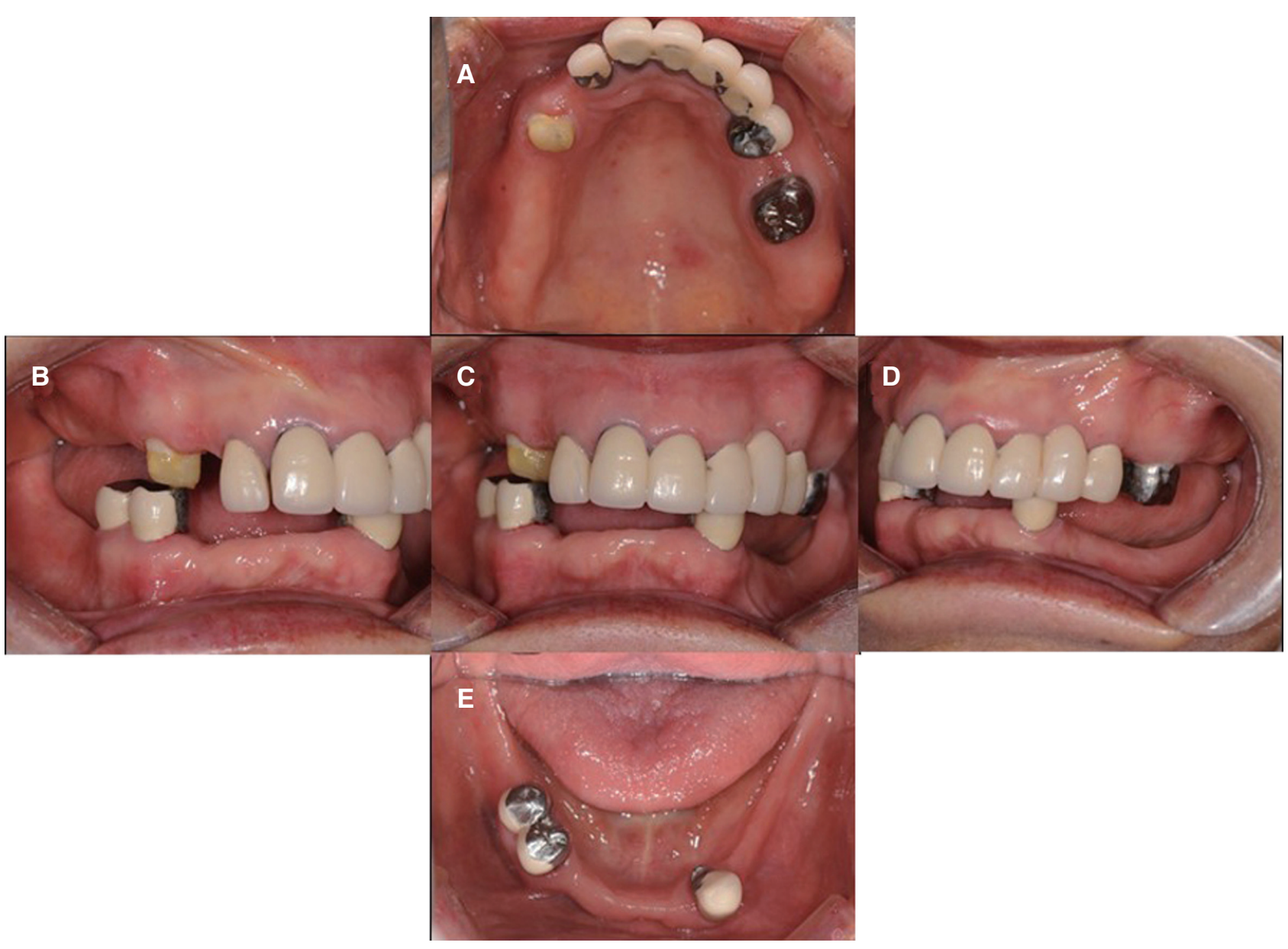

Fig. 2. Intra-oral status in the initial examination. (A) Maxillary occlusal view, (B) Right lateral view, (C) Frontal view at maximum inter-cuspal position, (D) Left lateral view, (E) Mandibular occlusal view. 
조 국소의치의 유지장치는 Locator ${ }^{\circledR}$ 부착장치(Zest Anchors Inc. Escondido, USA)로 선택하였다.

교합면간 거리, 전정 간 거리, 안모 계측, 심미, 발음 등 을 참고하여 수직고경 평가 후 기존의 수직고경을 유지 하기로 하였다. 이상적인 교합평면을 가지도록 전악 납 형 형성 시행하였고, 측방 운동 시 교합력 분산을 위해 좌 우 모두 견치부터 소구치까지 군기능 교합을 부여하였다 (Fig. 3). 이후 1 차 임시보철물을 제작하여, 환자에게 장 착하였다.

스텐트를 이용하여 컴퓨터 단층 사진을 촬영한 후, 부 족한 치조골 폭을 가지는 상악 우측 구치부에 치조골 증 대술(ridge augmentation)을 계획하였다(Fig. 4A). 하악 의 경우 양측 제 2 대구치 부위에 단일 임플란트 식립하여 후방 연장 임플란트 보조 국소의치의 구치부 지지를 담 당하도록 하였고, 치조골 폭이 부족한 하악 우측 구치부 는 임플란트 식립과 동시에 치조제 분할술(ridge split- ting)을 계획하였다(Fig. 4B, 4C).

상악 우측 구치부의 치조골 증대술 시행하였고, 12 개 월 후 컴퓨터 단층 사진을 촬영하여 안정적으로 골형성 됨을 확인하였다(Fig. $5 \mathrm{~A}$ ). 치조골의 높이를 얻기 위해 osteotome을 이용한 치조정 접근법으로 점막거상술(sinus lifting)시행과 동시에 \#15, 16, 17 임플란트를 식립 하였고, \#25, 27 위치에도 동시에 임플란트(\#15: $4.0 \times$ $10 \mathrm{~mm}, \# 16,17: 4.5 \times 10 \mathrm{~mm}, \# 25: 3.6 \times 10 \mathrm{~mm}, \# 27$ : $5.0 \times 10 \mathrm{~mm}$ (Superline, Dentium, Seoul, Korea))를 식 립하였다. 상악 우측 구치부 임플란트 식립 3개월 후 이 차 수술을 통하여 치유지대주를 연결하고 낮은 협측 전 정의 높이와 좁은 부착치은의 폭을 회복하기 위해 치근 변위판막술과 유리치은이식술을 시행하였다. 하악의 우 측 구치부에 치조제 분할술을 시행하고, \#37, 47 부위에 임플란트(\#37: $4.0 \times 10 \mathrm{~mm}, \# 47: 4.0 \times 12 \mathrm{~mm}$ (Superline, Dentium))를 식립하였다(Fig. 5B).

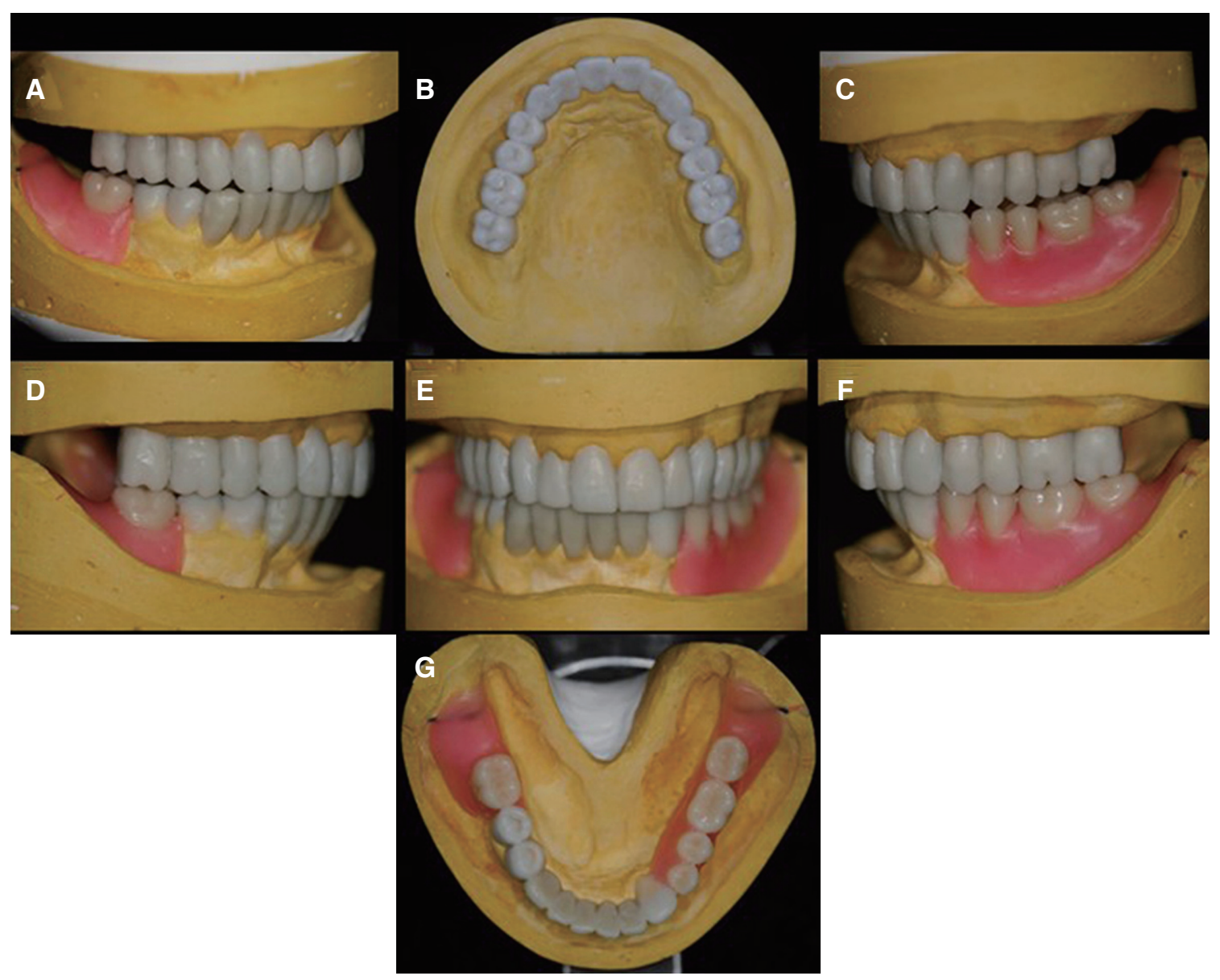

Fig. 3. Diagnostic wax-up model. (A) Lateral movement- right side: group function, (B) Maxillary occlusal view, (C) Lateral movement- left side: canine guidance, (D) Right lateral view, (E) Frontal view, (F) Left lateral view, (G) Mandibular occlusal view. 


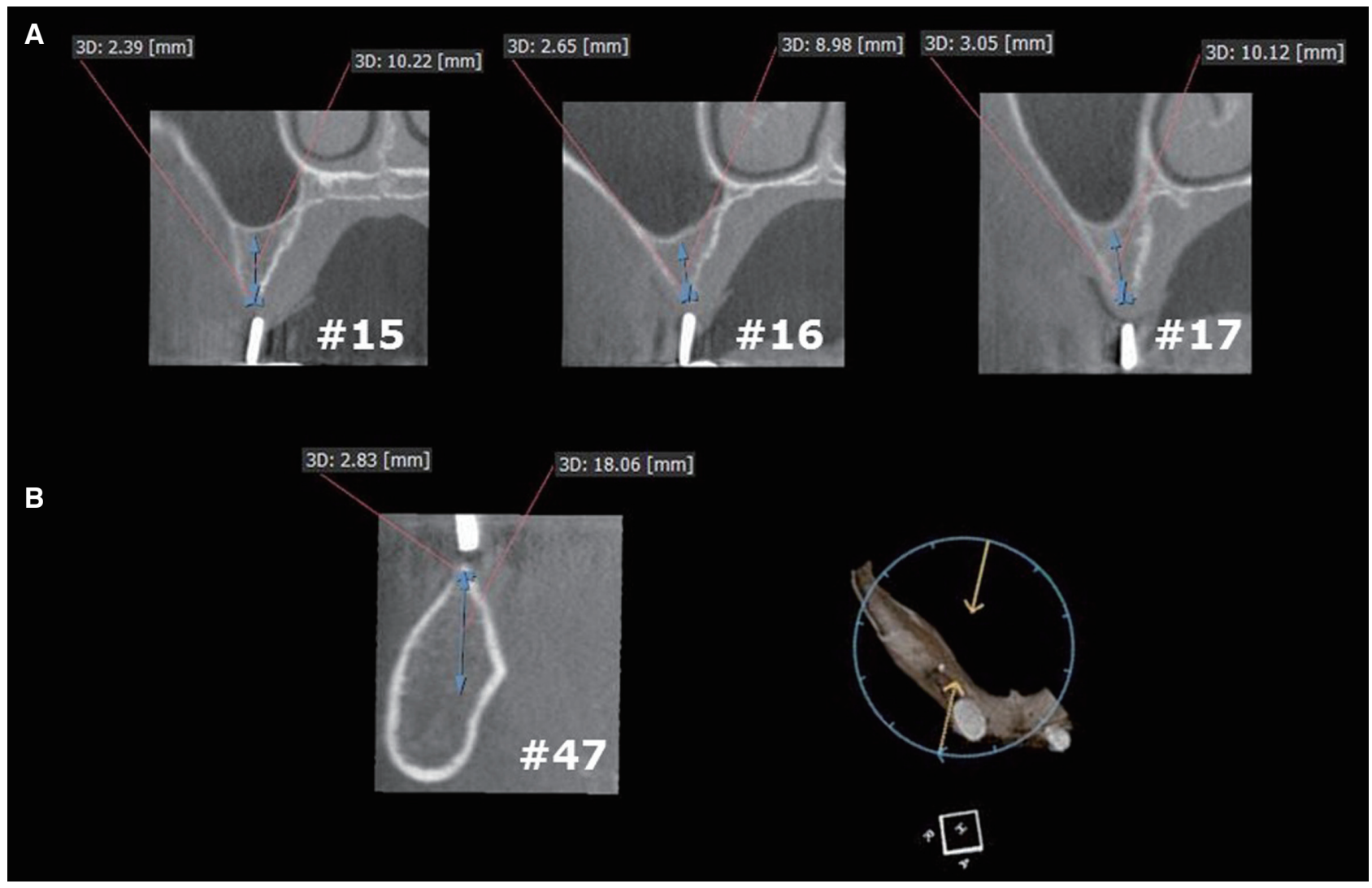

Fig. 4. Computed tomography (CT) images of \#15,16, 17 and 47 before guided bone regeneration. (A) Width of alveolar bone insufficient for \#15, 16 and 17 implantation before ridge augmentation. (B) Width of alveolar bone insufficient for \#47 implantation before ridge splitting.
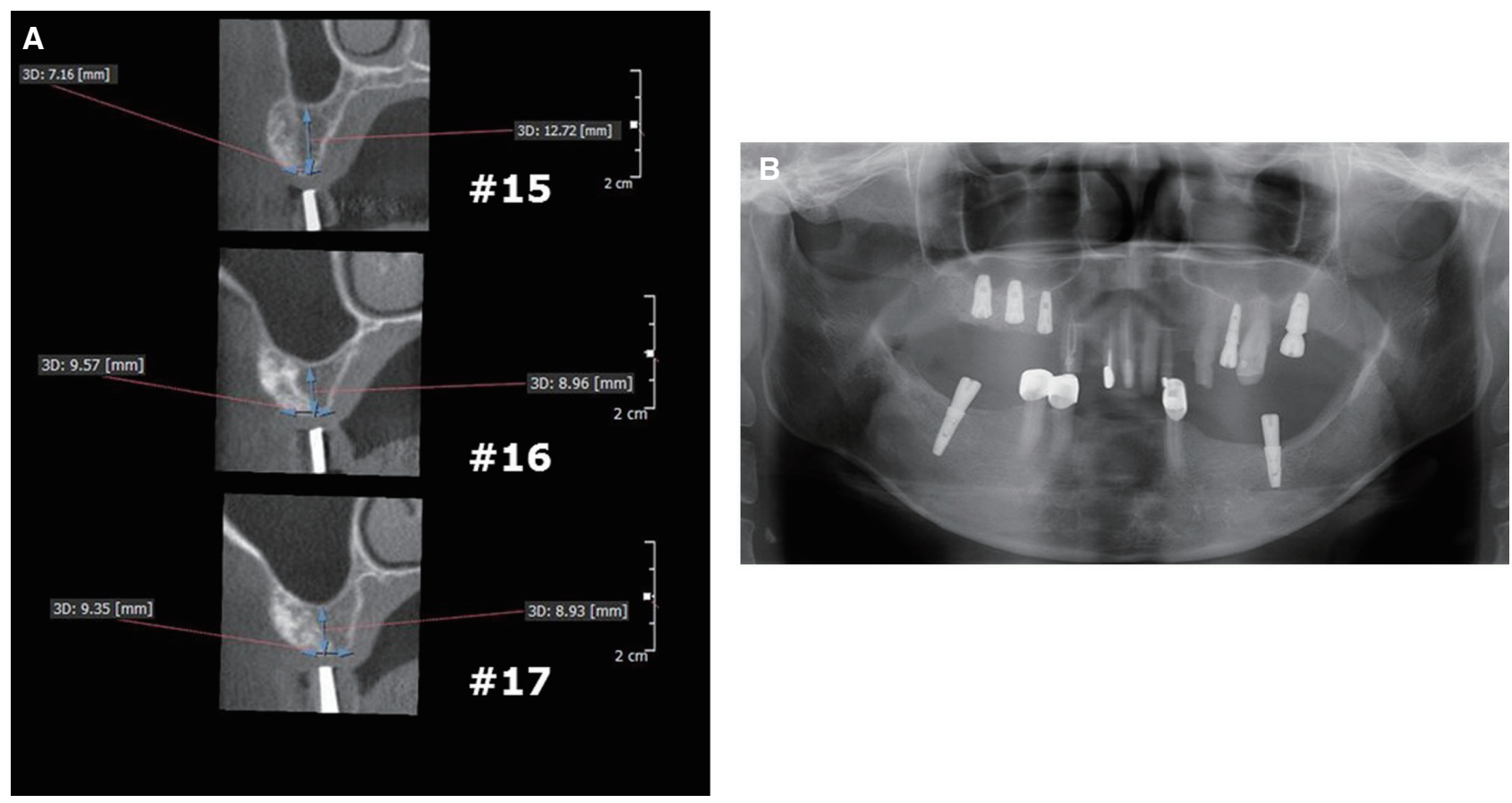

Fig. 5. Panoramic X-ray finding and CT images after surgery. (A) Computed tomography (CT) images after ridge augmentation on \#15, 16 and 17 area. (B) Panoramic X-ray view after implantation on \#15, 16, 17, 25, 27, 37 and 47. 
이후 임플란트를 포함한 인상을 채득하여 제작한 주모 형을 교합기에 부착하였다. 진단 납형 형성을 반영하여 최종보철물과 최대한 유사하도록 임시보철물을 제작하 여 구강내 장착하였다(Fig. 6).

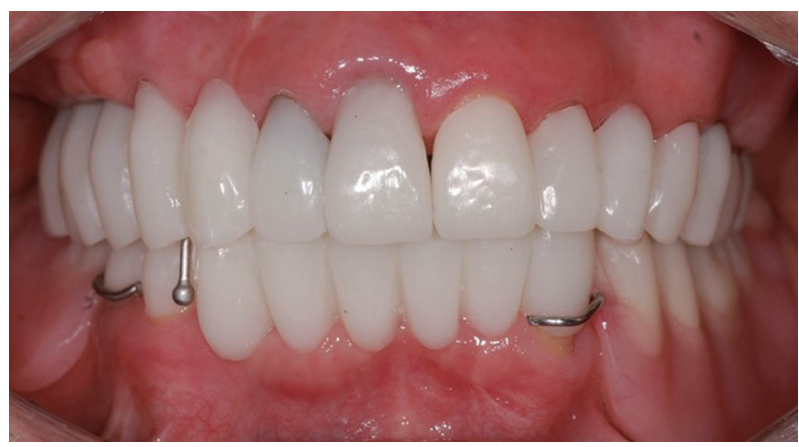

Fig. 6. Frontal view of 2 st provisional restoration.
환자는 2 개월 간 2 차 임시보철물 사용 후 심미적, 기능 적으로 매우 만족해하여, 최종보철물을 제작하기로 하 였다. 임플란트 지대주는 $\mathrm{CAD} / \mathrm{CAM}$ 시스템을 이용한 맞춤형 티타늄 지대주(Myplant, Raphabio Co., Seoul, Korea)로 제작하였고, 최종 전악 납형 형성 시행 후 맞 춤형 지대주를 연결한 최종 모형과 납형 형성 모형을 double scanning (Identica, Medit, Seoul, Korea) 하였다. 구치부는 단일 지르코니아(Prettau, Zirkozahn, South Tyrol-Gais, Italy)로, 상, 하악 6 전치는 지르코니아 코어 (Prettau) 제작 후 상부 도재(IPS e.max Ceram, Ivoclar Vivadent, Schaan, Liechtenstein)를 축성하여 최종보철 물을 제작하였다. 맞춤형 지대주를 구강 내에 체결하고, 최종 고정성 보철물을 합착하였다(Fig. 7).

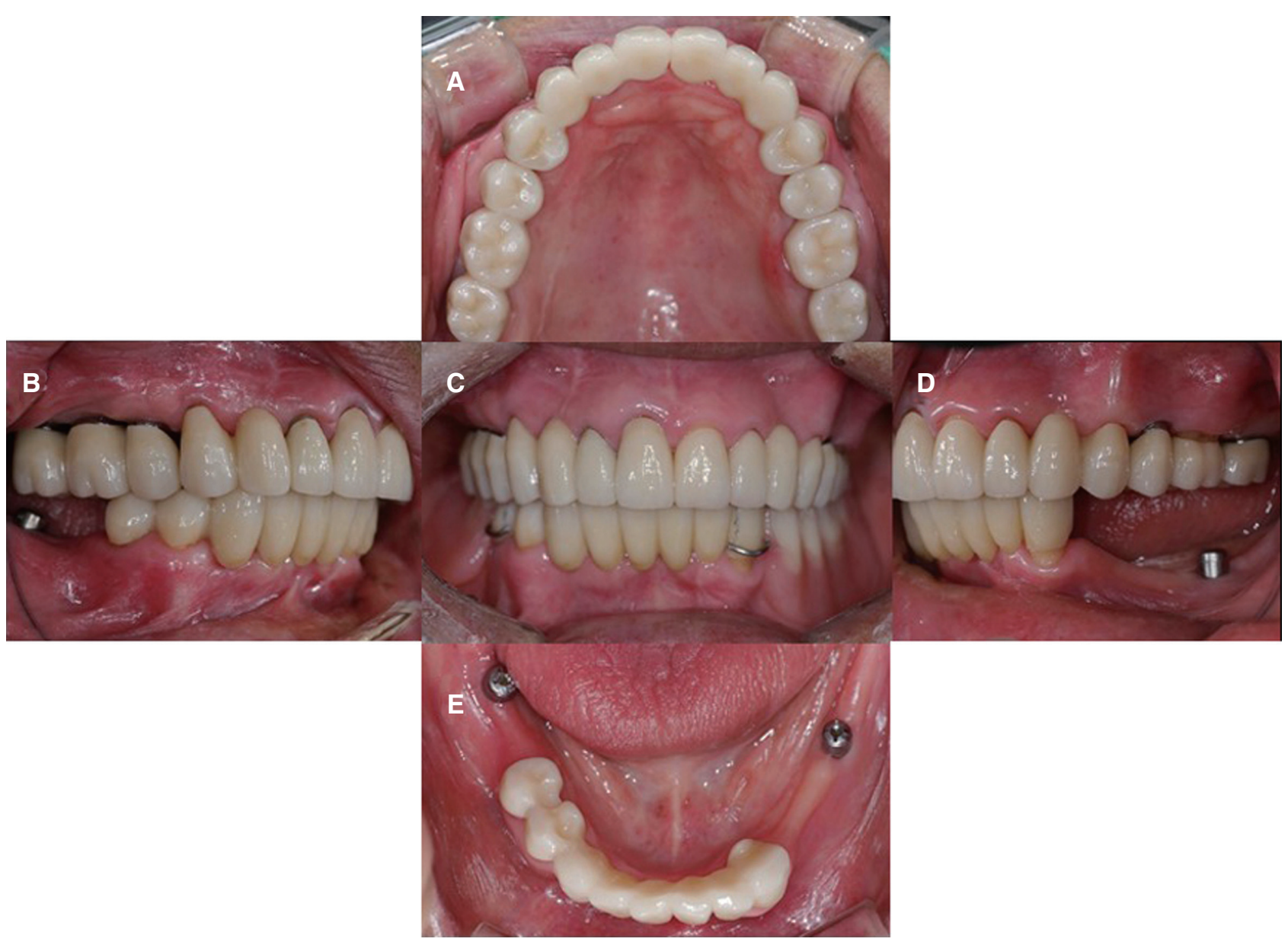

Fig. 7. Definitive fixed prosthesis was delivered. (A) Maxillary occlusal view, (B) Right lateral view, (C) Frontal view at maximum inter-cuspal position, (D) Left lateral view, (E) Mandibular occlusal view. 
하악의 임플란트 보조 국소의치 제작을 위하여 \#37, 47 부위 임플란트에 Locator ${ }^{\circledR}$ abutment 체결 후 비가역 성 친수성 인상재로 예비인상 채득하였다. 개인트레이를 제작하여 변연 형성 후 부가중합형 실리콘 인상재(Aquasil ultra LV, Dentsply Caulk, Milford, USA)를 이용하여 최종 인상채득 하였다. 이후 통법 대로 국소의치를 제작 하여 구강 내에 장착하고, 교합조정을 통해 전방 운동 시 구치부 이개와 측방운동 시 좌우측 군기능 교합 이루고 있음을 확인하였다(Fig. 8).

최종 의치 장착 2 주 후 Locator ${ }^{\circledR}$ 부착장치를 직접법으 로 부착하고, 하악 임플란트 보조 국소의치를 pick up 인 상 채득하였다. 이후 기존의 인공치 교합면을 삭제한 후 (기능 교두: $2 \mathrm{~mm}$, 비기능 교두: $1.5 \mathrm{~mm}$, 치경부에서 변 연 두께: $1 \mathrm{~mm}$ ) double scanning법으로 제작한 지르코니 아 교합면으로 교체하였다(Fig. 9, 10). 환자에게 구강위 생 및 의치 관리에 대한 교육을 하였고, 정기적으로 내원 하여 임상 및 방사선 검사를 시행하기로 하였다.

\section{고찰}

임플란트 보조 국소의치에서 식립된 임플란트에 대한 여러 후향적 연구들에서 생존율은 $95-100 \%$ 로 높게 나 타나며, ${ }^{7-10}$ 비록 많은 증례에서 장기간에 걸쳐 검증되었 다고 할 수 없으나 후방 무치악 부위에서 소수의 임플란 트만으로도 충분히 의치를 지지할 수 있을 것으로 기대 된다.

Keltjens 등은 가능한 임플란트가 후방에 위치하는 것 이 최대의 의치 안정 효과를 낼 수 있으며, 하악의 후방 연장 무치악에서 6-8 mm 길이와 최소 $2.5 \mathrm{~mm}$ 이상의 임플란트면 충분히 기능할 수 있다고 주장하였다. ${ }^{4}$ 한편 Verri 등 과 Cunha 등 ${ }^{11}$ 은 유한요소분석 실험에서 가능 한 길이가 길고, 직경이 큰 임플란트의 식립을 추천하였 다. 또한 식립 위치에 대하여 Cunha 등 ${ }^{11}$ 은 제1대구치 위 치에 임플란트를 식립했을 때 의치의 변위량이 가장 작 고, 제 2 소구치 부위에 식립했을 때 지대치의 스트레스 분

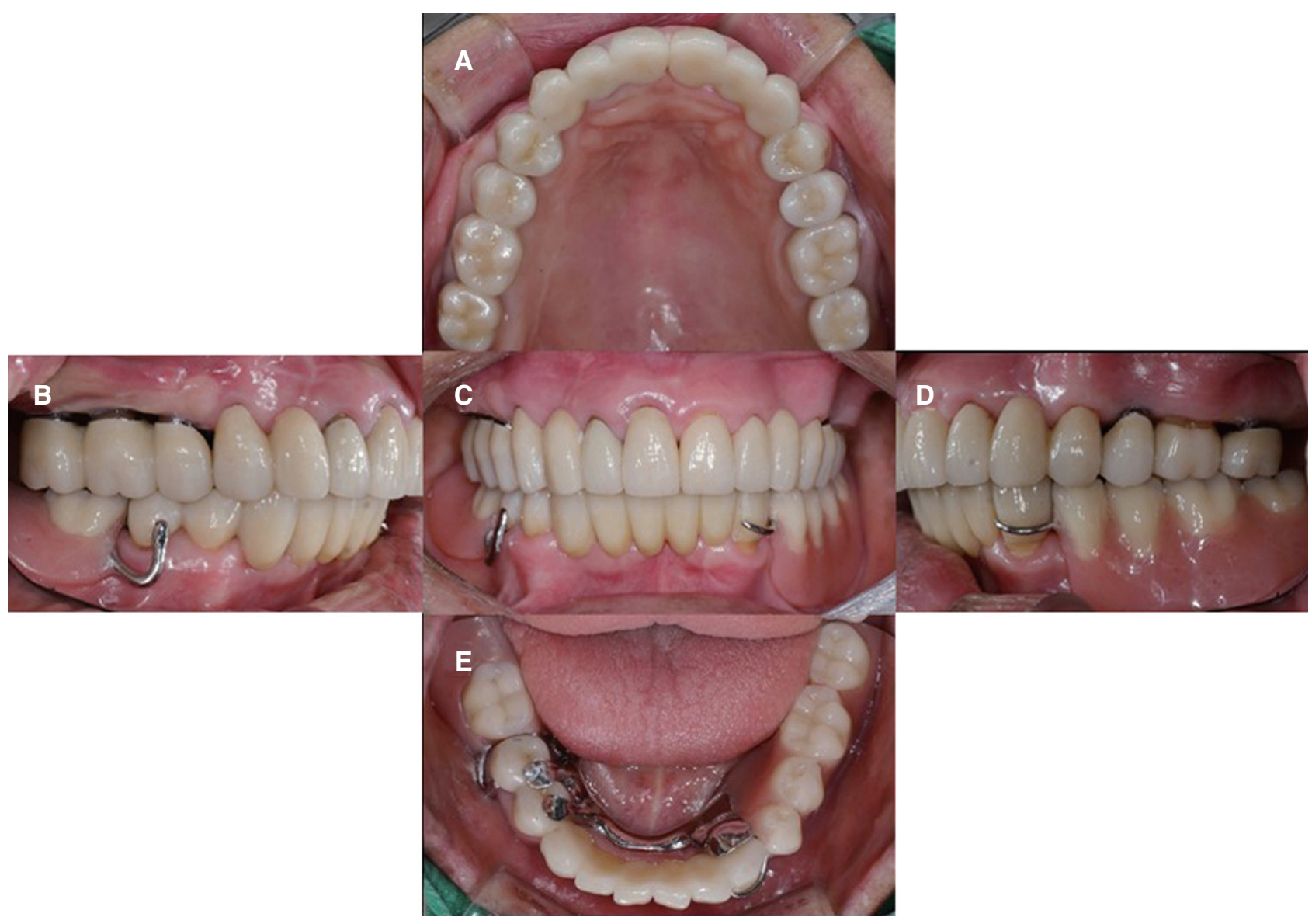

Fig. 8. IARPD was delivered. (A) Maxillary occlusal view, (B) Right lateral view, (C) Frontal view at maximum inter-cuspal position, (D) Left lateral view, (E) Mandibular occlusal view. 


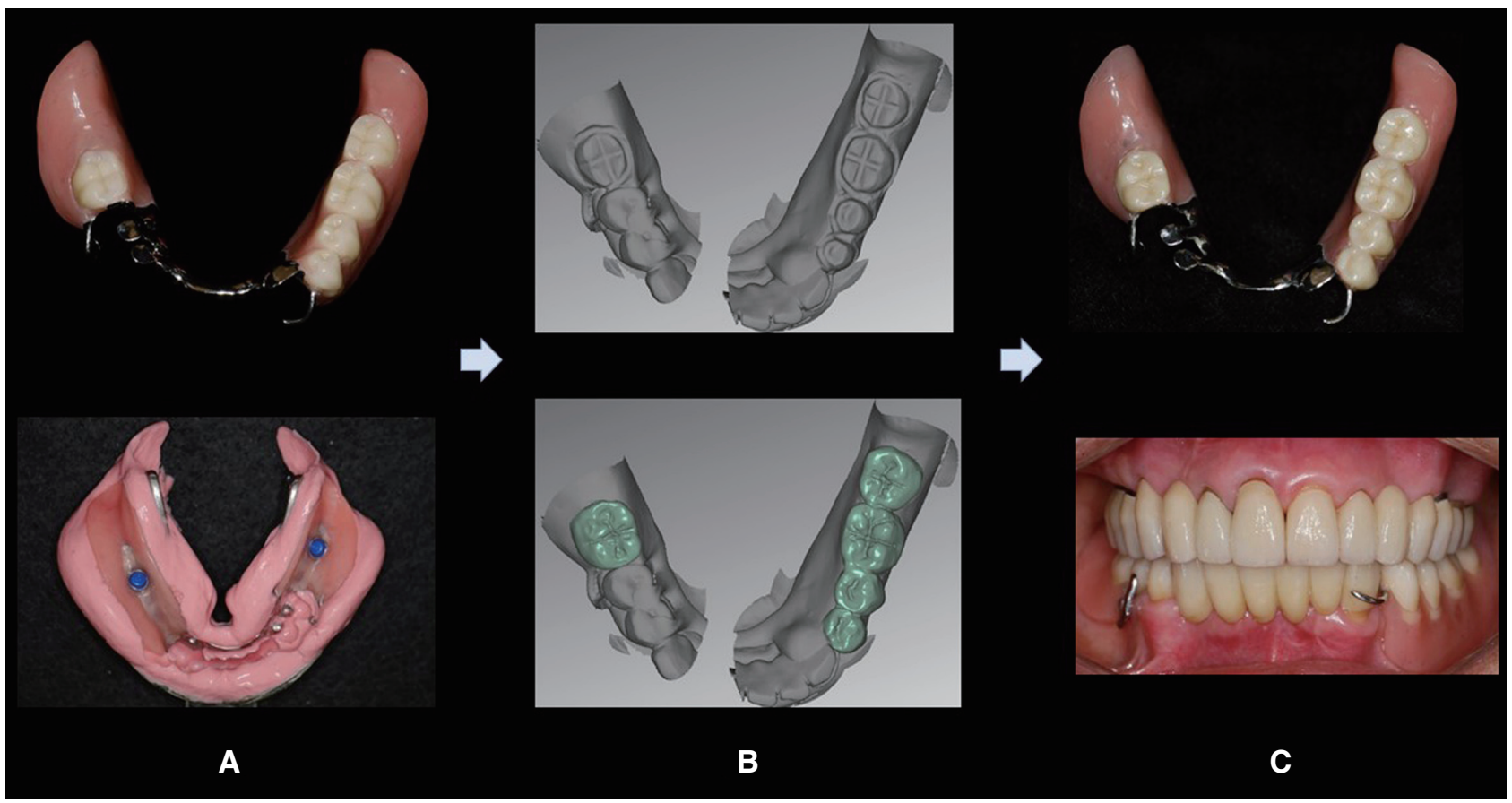

Fig. 9. Replacement from resin occlusal plane with zirconia occlusal plane replacement of occlusal plane from resin to zirconia. (A) Pick-up impression of IARPD with artificial resin teeth using irreversible hydrocolloid materials, (B) Preparation of the artificial resin teeth and fabrication of zirconia occlusal plane using/through double scanning method, (C) Final denture after cementation of zirconia occlusal prosthesis on the occlusal surface.

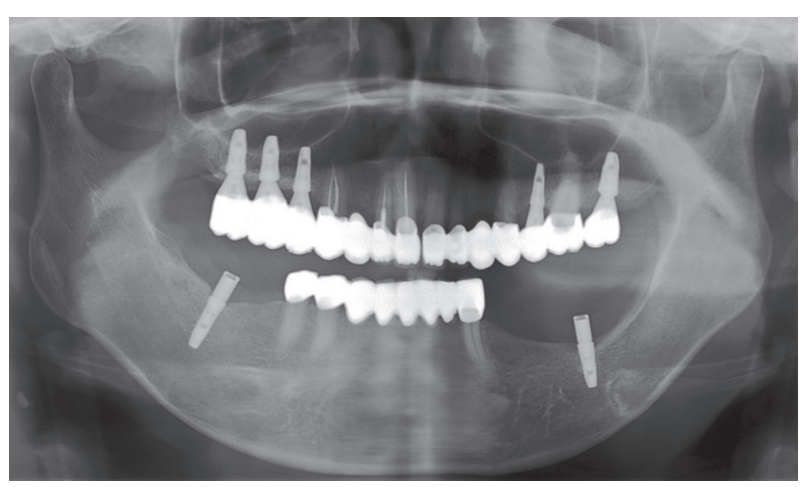

Fig. 10. Post-treatment panoramic radiograph.

산에 더 나은 결과를 보인다고 하였다. 이와는 달리 Kim 등 $^{12}$ 은 제 1 대구치 부위에 임플란트를 식립하는 것은 임 플란트에 심한 응력이 집중되고 후방 무치악 부위에도 응력이 많이 작용하므로 임플란트 식립 위치는 제 2 대구 치 부위 혹은 그 후방이 더 적절하다고 하였다. 본 증례에 서는 제한된 치조골 폭과 길이 내에서 가능한 큰 임플란 트를 선택하였고, 임플란트 후방 무치악 부위의 응력과
단일 임플란트에 가해지는 응력을 감소시키기 위해 가능 한 무치악부의 후방에 식립하고자 하였다.

한편 Wismeijer 등 ${ }^{13}$ 은 양측성 후방연장 무치악 부위에 임플란트를 식립하고 치유 지대주를 이용하여 지지만을 부여한 경우와, 부착장치를 연결하여 지지와 유지를 부 여한 경우 중 후자가 더 만족스러운 결과를 보였다고 보 고하였다. Pellizzer 등 ${ }^{14}$ 도 유한 요소 분석을 통해 임플란 트 보조 국소의치에서 사용될 수 있는 여러 가지 종류의 retention system의 효과를 비교하였는데, 지지만을 부여 한 경우 보다 부착장치를 사용한 경우가 의치상 하방의 응력 분산에 더 효과적임을 보여주었다. 이에 본 증례에 서는 resilient 부착장치인 Locator ${ }^{\circledR}$ 부착장치를 선택하여 임플란트에 부착하여 부가적인 유지를 부여하였다. 이는 작은 악간 거리에도 사용 가능하고, 수직적인 탄성이 있 어 응력 완화 효과를 지니며 임플란트 식립 각도를 보완 및 유지력의 크기 조절도 가능하여 임플란트 보조 국소 의치의 유지장치로 적합하다고 보고되고 있다. ${ }^{15}$

본 증례에서 하악의 양측 제 2 대구치 부위에 임플란트 를 식립하여 치아-조직 지지의 후방 연장 국소의치를 치 아-임플란트 지지로 변환하고, Locator ${ }^{\circledR}$ 부착장치를 이 
용하여 추가적인 유지를 부여한 후 환자는 기존에 사용 했던 하악의 후방 연장 국소의치에 비해 새로운 의치의 유지 및 안정, 저작 등에 매우 만족해하였다. 상악의 지르 코니아 교합면과 대합되는 하악 의치의 인공치의 마모에 의한 대합치의 추가적 정출을 예방하기 위하여 인공치의 교합면을 지르코니아로 교체하였다. Ghazal 등 ${ }^{15}$ 은 레진 인공치와 세라믹 인공치의 two-body wear 실험 결과, 교 합과 수직고경을 유지하고 마모 저항성을 증가시키기 위 하여 대합치가 자연치이거나 세라믹 교합면을 갖는 경우 세라믹 인공치를 사용할 것을 추천하였다.

이후 주기적인 임상 및 방사선 검사를 실시할 예정이 며, 추후 장기간 사용 시 발생할 수 있는 잔존치조제의 흡수에 따른 의치상의 침하를 예방하기 위하여 주기적인 의치상의 이장(relining)을 실시해야 할 것으로 사료된다.

\section{결론}

본 증례는 기울어진 교합평면을 가진 하악의 양측성 후방 연장 국소의치 환자에서 심미적이고 기능적인 교합 평면을 가지는 고정성 및 가철성 보철물을 이용하여 전 악 수복하였다. 의치상의 침하를 막기 위해 후방 구치부 에 임플란트를 식립하여 의치를 지지하도록 하고 인공치 의 마모를 막기 위해 의치의 교합면을 지르코니아로 교 체함으로써 대합치의 정출을 방지하고 바로 잡은 교합평 면이 장기간 유지되도록 하였다.

\section{ORCID}

A-Reum Han http://orcid.org/0000-0002-9432-7244

Tae-Min Kwon http://orcid.org/0000-0002-6640-2403 Kyoung-A Kim http://orcid.org/0000-0002-2923-5351 Jae-Min Seo http://orcid.org/0000-0001-5095-4046

\section{References}

1. Verri FR, Pellizzer EP, Rocha EP, Pereira JA. Influence of length and diameter of implants associated with distal extension removable partial dentures. Implant Dent 2007;16:270-80.

2. Shahmiri RA, Atieh MA. Mandibular Kennedy Class I implant tooth borne removable partial denture: a systematic review. J Oral Rehabil 2010;37: 225-34.
3. Ohkubo C, Kurihara D, Shimpo H, Suzuki Y, Kokubo Y, Hosoi T. Effect of implant support on distal extension removable partial dentures: in vitro assessment. J Oral Rehabil 2007;34:52-6.

4. Keltjens HM, Kayser AF, Hertel R, Battistuzzi PG. Distal extension removable partial dentures supported by implants and residual teeth: considerations and case reports. Int J Oral Maxillofac Implants 1993;8:208-13.

5. Giffin KM. Solving the distal extension removable partial denture base movement dilemma: a clinical report. J Prosthet Dent 1996;76:347-9.

6. Sato M, Suzuki Y, Kurihara D, Shimpo H, Ohkubo C. Effect of implant support on mandibular distal extension removable partial dentures: relationship between denture supporting area and stress distribution. J Prosthodont Res 2013;57:109-12.

7. Grossmann Y, Levin L, Sadan A. A retrospective case series of implants used to restore partially edentulous patients with implant-supported removable partial dentures: 31-month mean follow-up results. Quintessence Int 2008;39:665-71.

8. Mitrani R, Brudvik JS, Philips KM. Posterior implants for distal extension removable prostheses: a retrospective study. Int J Periodontics Restorative Dent 2003;23:353-9.

9. Mijiritsky E, Ormianer Z, Klinger A, Mardinger O. Use of dental implants to improve unfavorable removable partial denture design. Compend Contin Educ Dent 2005;26:744-6, 748, 750 passim.

10. Bortolini S, Natali A, Franchi M, Coggiola A, Consolo U. Implant retained removable partial dentures: an 8 year retrospective study. J Prosthodont 2011;20:168-72.

11. Cunha LD, Pellizzer EP, Verri FR, Pereira JA. Evaluation of the influence of location of osseointegrated implants associated with mandibular removable partial dentures. Implant Dent 2008;17:278-87.

12. Kim JH, Cho JH, Lee CH. Influence of the length and location of implants on distal extension removable partial dentures: finite element analysis. J Dent Rehabil Appl Sci 2015;31:186-94.

13. Wismeijer D, Tawse Smith A, Payne AG. Multicentre prospective evaluation of implant-assisted mandibular bilateral distal extension removable partial 
dentures: patient satisfaction. Clin Oral Implants Res 2013;24:20-7.

14. Pellizzer EP, Verri FR, Falcón-Antenucci RM, Goiato MC, Gennari Filho H. Evaluation of different retention systems on a distal extension remov- able partial denture associated with an osseointegrated implant. J Craniofac Surg 2010;21:727-34.

15. Ghazal M, Yang B, Ludwig K, Kern M. Two-body wear of resin and ceramic denture teeth in comparison to human enamel. Dent Mater 2008;24:502-7. 


\section{경사진 교합평면을 갖는 환자에서 임플란트 보조 국소의치를 이용한 전악 수복 증례}

\section{한아름 ${ }^{1}$, 권태민 ${ }^{1}$, 김경아 ${ }^{2}$, 서재민 ${ }^{1 *}$}

${ }^{1}$ 전북대학교 치의학전문대학원 치과보철학교실 및 구강생체과학연구소

${ }^{2}$ 을지대학교 의과대학 치과학교실

임플란트를 보조적으로 이용함으로써 후방 연장 국소의치에 부가적으로 유지와 지지를 얻는 임플란트 보조 국소의치 (implant-assisted RPD, IARPD)에 대한 관심이 증가하고 있다. 본 증례는 장기간 후방연장 국소의치의 사용으로 인하여 심하게 기울어진 교합평면을 가진 부분 무치악 환자에서 상악의 고정성 보철 수복과 하악의 지르코니아 교합면을 가지 는 임플란트 보조 국소의치를 이용하여 심미적이며 장기적으로 안정적인 교합평면을 가지도록 전악 수복하였으며, 기능 적으로 만족스러운 결과를 얻었기에 이를 보고하고자 한다.

(구강회복응용과학지 2016;32(3):214-23)

주요어: 임플란트; 임플란트 보조 국소의치; 부분 무치악; 교합평면 